\title{
Sekse- en genderdualiteit in discussie \\ Spreken over mannelijk en vrouwelijk in kerk en theologie
}

\author{
D.J. Steensma
}

\begin{abstract}
Speaking about two sexes and two kinds of gender connected with those sexes is the consequence of an ideology that disconnects the gender role and identity from the sex. Gender identity is according to this ideology a choice. The notion of two sexes is a modern invention; premodernity knew of only one sex. The experience of friction between sex and gender identities reinforces uncertainty, as does that of persons who have both male and female sexual characteristics. Some theologians argue in favour of abandoning the binary male-female model of human sexuality. This article argues that contemporary discussions of human sexuality challenge church and theology in the tradition of the Reformation to think through and define their position.
\end{abstract}

Eeuwenlang trok de kerk uit het scheppingsbericht de conclusie dat de mens is geschapen in twee geslachten. ${ }^{1}$ Karl Barth schreef dat het neutraliseren van de seksen een vorm van dehumanisering is. Boven man- of vrouw-zijn bestaat geen derde sekse. We mogen niet met eigenmachtige diepzinnigheid beter willen weten dan God. De grenzen die Hij heeft getrokken, moeten we erkennen en respecteren. Alles is in orde zolang en voor zover man en vrouw zich van hun sekse bewust zijn, daarbij oprecht blij zijn en blijven, en God ervoor kunnen danken dat zij mensen zijn met juist de desbetreffende sekse. Er is wanorde als mensen een hoger mens-zijn verlangen, een afkeer krijgen van hun man- of vrouw-zijn, dit als een last ervaren en zich daarvan zouden willen bevrijden. De mens bestaat nooit en nergens als mens an sich, maar altijd en overal als menselijke man of menselijke vrouw, die 'geheel anders' ten opzichte van elkaar zijn, aldus Barth. ${ }^{2}$ Sinds deze woorden is er veel veranderd. Ook in de theologie.

1 Met dank aan prof.dr. M. den Heijer voor diens commentaar op een eerdere versie van dit artikel.

2 Karl Barth, Kirchliche Dogmatik III/2, Zollikon-Zürich, 1948, 344-346; ibid. III/4, ZollikonZürich, 1951, 129.173-177. 


\section{Onrust}

Er is een tendens in de samenleving die zich keert tegen een traditioneel spreken over sekse en gender. Deze tendens zorgt voor onrust, ook onder gelovigen wereldwijd. Die onrust is onder meer verwoord door paus Franciscus. In zijn apostolische exhortatie over de liefde in het gezin, Amoris laetitia (2015), stelt hij dat de 'genderideologie' - een uitdrukking die vooral door Rome wordt gebruikt - het verschil en de natuurlijke wederkerigheid van man en vrouw ontkent. Deze ideologie holt daarmee de antropologische basis van het gezin uit. ${ }^{3}$

Deze onrust geeft reden tot bezinning, ook voor de gereformeerde ethiek. Daaraan wil dit artikel een bijdrage leveren. Het artikel begint met een schets van de denkbeweging - ook wel gendertheorie genoemd - die zich keert tegen het traditionele spreken over sekse en gender. Een andersoortige kritiek op het binaire man-vrouwmodel komt uit de hoek van natuurwetenschappen, die een dieper inzicht hebben verkregen in de mannelijke en vrouwelijke bestaanswijze, vooral ook wat de biologische, hormonale en genetische kant betreft. Wat mannelijk- of vrouwelijk-zijn betekent, is niet altijd even duidelijk. Daarbij gaat dit artikel ook kort in op de problematiek van intersekse en genderdysforie. Daarnaast hebben historische wetenschappen erop gewezen dat het spreken over twee seksen een uitvinding van de moderne tijd is. Als dat inderdaad het geval is, kan de kerk daar dan nog wel over blijven spreken? Vanuit de theologie is gereageerd op deze gedachten en inzichten. Sommigen stellen dat de kerk ook moet spreken over een 'derde sekse'. Hoe moet de kerk die staat in de traditie van de Reformatie, reageren op genoemde gedachten?

\section{Deconstructie}

Volgens de zogenaamde gendertheorie is genderidentiteit een sociale constructie. Deze theorie werd vooral naar voren gebracht in de derde feministische golf. In de eerste golf streden vrouwen voor hun rechten op allerlei terreinen. De tweede golf, die opkwam in het midden van de twintigste eeuw, keerde zich vooral tegen een vanzelfsprekende koppeling van genderrol aan biologische sekse. Een dergelijke toedeling werd voor vrouwen als vernederend beschouwd en zou vooral dienen om de door mannen gedomineerde status-quo te handhaven. In de derde golf lag de focus op datgene wat achter de (biologische) sekse ligt. Hiermee kwam een motief naar voren dat reeds door Friedrich Nietzsche was verwoord, namelijk dat er geen 'zijn' aanwezig

3 Franciscus, Amoris Laetitia. Over liefde in het gezin. Postsynodale apostolische exhortative. Werelddocumenten 36. Ed. Bisschoppenconferentie van België, Brussel, z.j. [2015], nr.56. 
is achter doen en worden. ${ }^{4}$ Deze derde golf sloot aan bij de postmoderne stroming van het structuralisme. Volgens deze stroming, waarvan Claude LéviStrauss een belangrijke vertegenwoordiger was, construeert de maatschappij het vrouw-zijn: er is geen vast, boven-historisch 'zijn' achter deze constructie. De cultuur legt de natuur een betekenis op. Deze natuur bestaat slechts uit ruw materiaal. De betekenisverlening daarvan gebeurt door de machthebbers in de maatschappij. Mannen dus. Het biologisch geslacht is derhalve niet normatief voor de maatschappelijke rol van de vrouw. Het 'zelf ligt achter het geslacht en krijgt inhoud door zijn plaats in een groter systeem.

Michel Foucault dacht in ditzelfde spoor verder. Hij stelde dat elke interpretatie een uiting van macht is: de werkelijkheid bestaat uit niets anders dan een stroom van ervaringen. Wie zijn eigen interpretatie daaraan verbindt, gebruikt geweld. Maar als postmodernist en poststructuralist ontkende hij de mogelijkheid van kennis van de werkelijkheid.

Het werk van Foucault en andere postmodernisten was een bron van inspiratie voor feministen. Simone de Beauvoir schreef: 'Je komt niet ter wereld als vrouw, je wordt vrouw. Het beeld van de vrouw en daaraan verbonden haar plaats in de maatschappij wordt niet door enig biologisch, psychisch of economisch noodlot bepaald. ${ }^{5}$ De rol van de samenleving is beslissend in de vorming van de vrouwelijke identiteit. De samenleving werkt wat dat betreft onderdrukkend. De Beauvoir pleitte voor keuze door vrouwen zelf in die beeldvorming, ook al zijn de keuzemogelijkheden niet onbeperkt, omdat haar lichaam en sociale omgeving beperkingen opleggen.

Daarna klonken stemmen die ook deze beperkingen ter discussie stelden. Shulamith Firestone bijvoorbeeld wilde de band tussen (biologische) sekse en (sociale) gender nog losser maken. Het was volgens haar onbillijk dat alléén de vrouw de last moest dragen van typische 'vrouwenziekten' (zoals het krijgen van kinderen). Deze bevrijding kon volgens haar in de toekomst worden gerealiseerd door de ontwikkeling van nieuwe methodes van kunstmatige voortplanting. ${ }^{6}$ Ook Judith Butler gaf stem aan dit postfeminisme. Zij meende dat de toekenning van een specifieke genderrol aan de vrouw door de huidige samenleving deel uitmaakt van een politiek plan. De tweedeling in seksen is gebaseerd op een verkeerde metafysica. Gender moet 'gedenaturali-

4 Friedrich Nietzsche, De genealogie van de moraal. Een strijdschrift (red. Thomas Graftdijk en Hans Driessen), Amsterdam 2000, 37 (nr.13).

5 Simone de Beauvoir, De tweede sekse. Feiten, mythen en geleefde werkelijkheid. Red. Jan Hardenberg, Utrecht $1990^{10}, 323$.

6 Shulamith Firestone, The Dialectic of Sex. The Case for Feminist Revolution, New York $1970,2015^{2}$. 
seerd' worden. Het binaire model van seksen is niet meer aan de orde. ${ }^{7} \mathrm{De}$ bevrijding van vrouwen zou steeds meer vorm moeten krijgen door middel van kunstmatige voortplanting, waarbij gedacht kan worden aan de kunstmatige baarmoeder en het maken van een eicel uit een huidcel. Instellingen die de scheiding tussen de geslachten in stand houden, moeten worden verboden.

Genderidentiteit wordt in deze gedachtengang een voorwerp van keuze, onafhankelijk van het biologische geslacht waarmee iemand geboren is. Het eigenlijke mens-zijn zou uitgaan boven de sekse. Los van de eigen mogelijkheid in het voortplantingsproces zouden er geen fundamentele verschillen tussen man en vrouw zijn. Mannelijkheid en vrouwelijkheid zeggen niets wezenlijks over mens-zijn. Deze gedachte werd in de vorige eeuw soms ver doorgevoerd: alsof mannelijk- of vrouwelijk-zijn maakbaar zouden zijn. Geruchtmakend was het werk van John Money (1921-2006), en de 'correctieve ingreep' die hij - na een mislukte besnijdenis - toepaste op Bruce (later: Brenda; nog weer later: David) Reimer. Money meende dat genderidentiteit voor een groot deel het resultaat van cultuur, opvoeding en conditionering is.

In deze gedachtegang is genderidentiteit vloeibaar geworden. ${ }^{8}$ In Engeland houden volgens krantenberichten uit 2019 Hobbit Humphrey en Jake England-Johns het geslacht van hun kind geheim totdat het kind, dat met 'het' of 'hen' wordt aangesproken, later zelf bepaalt welke sekse het wil aannemen. Heeft het eenmaal gekozen voor een sekse, dan staan er vier mogelijkheden van seksuele gerichtheid open: homoseksueel, lesbisch, heteroseksueel of biseksueel. Dit voorbeeld is tekenend: genderidentiteit als keuze, en dan ook daarbij de keuze van de seksuele gerichtheid. De sekse is niet vooraf gegeven. De tendens waarin aan mensen een keuze wordt gelaten, is ook in het onderwijs zichtbaar. In sommige instellingen in bijvoorbeeld Engeland, de VS en Canada mogen leerkrachten de leerlingen niet aanspreken met 'jongens en meisjes'. Als zij het wel nodig achten aan het geslacht te refereren, moeten zij zeggen: 'Jongen, meisje, beide of geen van beiden.'

\section{Intersekse en dysforie}

De bovengenoemde genderideologie richt zich op de deconstructie van het traditionele binaire man-vrouwmodel. Zo wordt twijfel ten aanzien van dit model in de samenleving gevoed en versterkt. Deze twijfel komt ook voort vanuit een geheel andere invalshoek, namelijk de oprechte zorg voor mensen die leed erva-

7 Judith Butler, Gender Trouble: Feminism and the Subversion of Identity, New York [1990] 2006.

8 Vgl. Zymunt Baumann, 'Foreword: On Being Light and Liquid', in: id., Liquid Modernity, Cambridge 2012, vii-xiv. 
ren met betrekking tot hun sekse en gender. Voor dat leed is de laatste decennia steeds meer aandacht gekomen. Deze aandacht werd onder meer gegenereerd door medisch-wetenschappelijk onderzoek. Dat onderzoek wees uit dat er niet altijd een duidelijke biologische scheidslijn tussen mannen en vrouwen bestaat.

Sommige mensen hebben zowel mannelijke als vrouwelijke geslachtelijke eigenschappen. Hun lichamelijke constitutie wijkt af van wat als normaal geldt. Bijvoorbeeld hun chromosomenpatroon is afwijkend. Het kan ook zijn dat een kind bij de geboorte ambigue genitaliën heeft. Er zijn allerlei vormen van interseks, waarbij anatomisch-biologisch geslachtskenmerken van beide seksen aanwezig zijn. Vroeger werd ook wel gesproken over hermafroditisme. In de omgang met diegenen die afwijkingen vertonen in het normale geslachtelijke patroon, zijn in de loop van de tijd fouten gemaakt. Sommigen werden onderworpen aan een 'medische' behandeling die meer schade bracht dan heling. Als bijvoorbeeld bij de geboorte de sekse niet duidelijk was, werd gekozen voor de mannelijke sekse en werden 'medische' ingrepen daarop toegepast. Later kon blijken dat de betrokken persoon zich helemaal geen jongen voelde, maar een meisje of geen van beiden.

Terecht wordt voor de problematiek van mensen met een intersekse conditie aandacht gevraagd. Ook binnen kerk en theologie. Verscheidene theologen ${ }^{9}$ stellen dat de kerk daarom het binaire man-vrouwmodel moet loslaten en zonder reserve een 'derde sekse' moet omarmen. Er wordt in dit verband ook gewezen op de positie van eunuchen in bijbelse tijden en de vroege kerk. ${ }^{10}$ Deze theologen verwerpen een direct beroep op de bijbeltekst die zegt dat God de mens mannelijk en vrouwelijk schiep (Gen.1,27): wie meent dat daar slechts wordt gesproken over twee seksen, gaat uit van een achterhaald mensbeeld. Genesis zou op een figuurlijke manier spreken en niets zeggen over een fundamentele dualiteit in het mens-zijn. Zo wordt - ook vanuit de theologie - het binaire man-vrouwmodel ter discussie gesteld.

Deze discussie wordt eveneens gevoed vanuit vragen rondom genderdysforie. Wie lijdt aan deze dysforie, heeft lichamelijk gezien de ene sekse en psychisch de andere sekse. Is deze combinatie dan misschien een derde mogelijkheid naast de beide andere standaardmogelijkheden? Bij genderdysforie is de uiterlijke, anatomische ontwikkeling in de eerste levensjaren voorspoedig verlopen, maar ontstond in de verdere groei naar volwassenheid het gevoel van dysforie (neerslachtigheid) ten aanzien van de eigen geslachtelijkheid. De

9 Bijv. Megan K. DeFranza, Sex Difference in Christian Theology, Grand Rapids 2015; Adrian Thatcher, Redeeming Gender, Oxford 2016; Gerard Loughlin, 'Gender Ideology: For a “Third Sex” Without Reserve', in: Studies in Christian Ethics 31, 4 (2018), 471-482.

10 De Franze, Sex Difference, 68-106. 
identiteit die mensen dan ervaren, wijkt af van het anatomisch-biologische geslacht. Velen stellen dat de oorzaak ligt in de ontwikkeling van de hersenen. Deze zouden in het proces van differentiatie (tot het derde of vierde jaar) een verkeerde afslag hebben genomen. Anderen wijzen (ook) op andere factoren. Deze dysforie kan in verscheidene gradaties voorkomen. Een ernstige vorm daarvan doet zich voor als mensen in een depressie geraken, een afkeer van hun lichaam voelen en niets anders wensen dan het lichaam te bezitten van de sekse die volgens hen bij hun (gender)identiteit past. In elk geval is ook bezinning op deze problemen ten aanzien van de mannelijke en vrouwelijke identiteit reden voor een gesprek over de dualiteit in seksen.

\section{Historische wetenschappen}

Een derde factor in dit verhaal raakt het spreken over man- of vrouw-zijn in de geschiedenis. Daarover is steeds meer bekend geworden. De huidige cultuur spreekt doorgaans over twee seksen, maar dat is niet altijd het geval

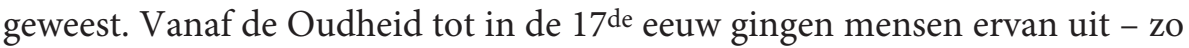
wordt gezegd - dat er slechts één sekse is.

Een mythe in het oude Griekenland verhaalt over de splitsing van de ene androgyne mens in de aanvang van de geschiedenis. Hij zou zijn gespleten als straf op zijn hoogmoed omdat hij had geprobeerd de hemel te veroveren. Vanaf dat moment was ieder mens incompleet. Hij kon pas weer compleet worden door de verbintenis met zijn wederhelft. Velen huldigden in de Oudheid de gedachte dat de mens van oorsprong androgyn is. Philo van Alexandrië bijvoorbeeld stelt in zijn uitleg van Genesis dat God eerst de idee mens schiep, die noch mannelijk noch vrouwelijk was. Ook andere Joodse schrijvers gingen daarvan uit en daarnaast auteurs in de vroege kerk en de Middeleeuwen.

Heel de Oudheid veronderstelde dat de mensheid slechts één sekse kent. Man- of vrouw-zijn was een kwestie van kwaliteitsverschil. De opvatting van de arts Claudius Galenus (130-210) zou tot ver in de Middeleeuwen de medische denkwereld hebben bepaald: de man was de meest perfecte uitvoering van het mens-zijn. Het mens-zijn van de vrouw kon zelfs als mislukt worden beschouwd. In de vroege kerk en ook daarna was er daarom twijfel over haar beeld-van-God-zijn.

De gedachte dat de mensheid is verdeeld in twee seksen, kreeg pas vanaf

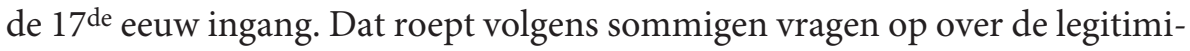
teit van deze gedachte. ${ }^{11} \mathrm{Zij}$ willen dan niet teruggaan naar het denken in ter-

11 Deze gedachten zijn vooral door Thomas Laqueur naar voren gebracht in zijn Making Sex. Body and Gender from the Greeks to Freud, Cambridge 1990. 
men van één sekse, maar kiezen voor een historische invulling van de seksegedachte. Ook verscheidene theologen stellen dat de gedachte van twee seksen tekortschiet. De theologie zou de gedachte van twee seksen hebben ingelezen in het scheppingsverhaal. Genesis zou iets anders bedoelen dan dat God twee seksen schiep. ${ }^{12}$ Vooral telt mee dat kerk en theologie rekening moeten houden met personen met een derde sekse, een intersekse conditie of genderdysforie. De twee-seksentheorie, die een uitvinding van de moderne tijd is, doet - zo wordt gezegd - voorkomen alsof de mensheid in feite uit twee soorten bestaat. Deze theorie vergroot daardoor de verschillen tussen mensen en daarmee ook intermenselijke conflicten. Daardoor kunnen vormen van ongelijkheid en seksisme nooit worden weggenomen. Dat geldt niet alleen voor een twee-seksenmodel dat uitgaat van een hiërarchie tussen man en vrouw (met een ontologische superioriteit voor het mannelijk 'zijnde'), maar ook voor een binair model dat de gelijkheid tussen mannen en vrouwen onderstreept.

De anglicaanse theoloog Adrian Thatcher keert zich tegen de gedachte dat de biologie de scheidslijn zou aangeven tussen man en vrouw. Hij stelt in plaats daarvan een christologisch model voor. ${ }^{13}$ Alleen dat model kan volgens hem recht doen aan de gelijkheid tussen de seksen. ${ }^{14}$ Dat model gaat ervan uit dat Christus het Hoofd van het transhistorische lichaam van de mensheid is. Daardoor wordt elk ander menselijk onderscheid gerelativeerd. Er zijn slechts categorieën of klassen. Daarom kan er beter niet meer worden gesproken over een mannelijk of vrouwelijk 'zijn' alsof er twee verschillende essenties bestaan, met eigen specifieke psychische en cognitieve eigenschappen, en eigen gedragingen. Er is niets anders dan een human continuum. ${ }^{15}$ Thatcher vindt dan ook dat de kerk zich niet moet focussen op het verschil tussen mensen, maar op relaties. De relatie tussen mensen - hoe hun genderidentiteit ook is - moet worden verlost. ${ }^{16}$ In Christus is er geen hiërarchie meer. Hij is het hoofd van de hernieuwde mensheid, bij alle verschillen die er blijven. Verschillen zijn geen reden tot verwijdering, maar juist een middel in de onderlinge verbondenheid. Thatcher verduidelijkt dit door een beroep te doen op de gedachte van de onderlinge verbondenheid van de drie-enige God.

12 Thatcher, Redeeming Gender, 34-83; DeFranza, Sex Difference, 107-150.

13 Ook DeFranza wijst op Christus als het ware beeld van God (Sex Difference, 239-289).

14 Thatcher, Redeeming Gender, 161-162.169.

15 Thatcher, Redeeming Gender, 141.169.

16 Thatcher, Redeeming Gender, 5-6.168. 


\section{Mensbeeld}

De bovenstaande gedachten vragen om een kritische reflectie. Gereformeerde ethiek kan niet anders dan constateren dat de gendertheorie of -ideologie een uiting van de tijdgeest is, die zich keert tegen God en zijn ordeningen. Dat manifesteert zich in deze problematiek vooral in een onderwaardering van het menselijk lichaam. Het spreken van God daarover wordt niet meer gehoord. God spreekt ook via de werken van zijn handen en eveneens via het menselijk lichaam. Daarmee is niet gezegd dat de oorzaak van alle lichamelijke tekortkomingen en gebreken direct aan God zou moeten worden toegeschreven. Wel is daarmee gezegd dat Hij de Schepper van de mens is. De gelovige mag dat ook zo beleven. Hij hoort onder andere óók door zijn lichaam heen het spreken van God. Hoewel de zondeval het verstaan van dit spreken heeft verstoord, klinkt dat spreken nog steeds. Hij spreekt ook door de mannelijke en vrouwelijke bestaanswijze. Van beide bestaanswijzen gaat een roeping uit, die om een antwoord vraagt. Weliswaar kan daarmee - bijvoorbeeld - niet worden gezegd dat een baarmoeder meteen de plicht tot huwelijk en het baren van kinderen inhoudt. Toch draagt de lichamelijke constitutie een boodschap in zich. Zij gaat terug op het werk van God.

In de hedendaagse cultuur overheerst de gedachte dat het persoon-zijn en het uiterlijke, lichamelijke bestaan twee zaken zijn die los van elkaar staan, waarbij het laatste ondergeschikt is aan het eerste. Het uiterlijke bestaan zou voorwerp van keuze zijn, instrument van het ik en ruw materiaal waarop dat ik vormend inwerkt. Maar daarmee wordt (het spreken van God door) de lichamelijke werkelijkheid sterk onderschat. Een markeringspunt in de ontwikkeling van de genoemde gedachte is Descartes. De ziel zou volgens Descartes over het lichaam beschikken zoals een arbeider over zijn werktuig. John Locke verbond het persoon-zijn nog sterker aan menselijk bewustzijn. Het lichaam is volgens hem een functioneel object, dat in zichzelf nauwelijks waarde heeft en onder beheersing van de wil staat.

$\mathrm{Na}$ de eeuw van de Verlichting ging in de westerse wereld dit voluntarisme de boventoon voeren: de wil werd dominant in de moraal, omdat - zo werd gedacht - juist daarin de mens zijn vrijheid kan beleven. Het verstand nam daarbij overigens nog wel een belangrijke plaats in. Immanuel Kant bracht zelfs op indrukwekkende wijze het rationalisme van de Verlichting in verband met de gedachte van de vrijheid van de menselijke wil. De wil gehoorzaamt dan - in vrijheid - een universele plicht, die voor elk redelijk wezen inzichtelijk is. $\mathrm{Na}$ Kant werd het verstand echter meer en meer ondergeschikt aan de leiding van de wil. Ondertussen bleef het wetenschapsideaal van Francis Bacon doorwerken, namelijk de idee dat het verstand het geëigende middel is waarmee de natuur kan worden beheerst ten dienste van het welzijn van mens en samenleving. 
Wetenschap en techniek werden - vooral vanaf de 19de eeuw - niet alleen instrumenten voor de beheersing van natuurlijke processen, maar ook voor de beheersing van sociale processen. In zijn Brave New World (1932) schetst Aldous Huxley hoe de techniek voor sociale stabiliteit moet zorgen. Uiteindelijk worden in deze 'nieuwe wereld' mens en samenleving gemanaged door techniek, conditionering en hersenspoeling. Wat Huxley echter niet beschreef - en mogelijk niet kon bevroeden - is het vloeibaar-worden (of: maken) van de seksen, dat in de loop van de $20^{\text {ste }}$ eeuw steeds meer werkelijkheid werd. Het lichaam is volgens dit beheersingsprincipe 'materiaal' dat het ware mens-zijn ter beschikking staat. Uiteindelijk leidt deze inzet tot de gedachte dat mensen hun eigen sekse zouden moeten kunnen bepalen - in elk geval de sociale en juridische sekse, los van hun anatomische kenmerken. De menselijke geest wordt beschouwd als de echte persoon en het lichaam heeft dan een louter instrumentele waarde. De 'wil' mag dan mogelijk uiteindelijk ook beschikken over functies in seksualiteit en voortplanting. De enige beperking is dan dat de vrijheid van de ander gerespecteerd moet worden en dat deze ander geen schade mag worden toegebracht. Deze gedachte wordt versterkt door de hedendaagse cultuur van individualisme en het streven naar de authenticiteit. ${ }^{17}$ Het criterium is dan het eigen gevoel en de zelfbeschouwing.

Deze ontwikkeling is echter een loochening van de mannelijke en vrouwelijke bestaanswijze. Man en vrouw worden vanuit hun eigen bestaanswijze geroepen tot verantwoording jegens God. Zij vullen elkaar in hun roeping aan. Ook al heeft de cultuur daarin een belangrijke stem, de invulling van deze roeping staat niet los van hun biologische sekse. ${ }^{18}$ Een theologie die vast wil houden aan het bijbelse getuigenis, zal over de dualiteit van man- en vrouw-zijn blijven spreken. Zij staat wat dat betreft tegenover een sterke tendens in de samenleving. Wel zijn ontwikkelingen in de samenleving een signaal voor kerk en christenen om voorzichtig te zijn met het koppelen van een specifieke rol aan het man- of vrouw-zijn. Als dat echter wel gebeurt, moet zij daarvoor verantwoording afleggen op basis van de Schrift waarin zij haar uitgangspunt neemt.

De kerk die trouw wil blijven aan het getuigenis van de Schrift, kan dit spreken over dualiteit niet loslaten. Zij kan daarom ook niet instemmen met diegenen die door middel van het spreken over een derde sekse het verlos-

17 Zie Charles Taylor, De malaise van de moderniteit, Kampen $2000^{11}$.

18 Over de zin van de sekse voor het mens-zijn: zie bijv. Maarten J. Verkerk, Sekse als antwoord. Verantwoording 12, Amsterdam 1997, 209-236; vgl. ook: Lisa Sowle Cahill, Sex, Gender \& Christian Ethics. New Studies in Christian Ethics, Cambridge [1996] 1999. 
sende werk van Christus willen onderstrepen. Daarmee is niet gezegd dat het verlossingswerk van Christus geen betekenis zou hebben voor diegenen die lijden onder gebrokenheid in hun sekse. Aandacht voor de desbetreffende problematiek is positief. Maar het verlossingswerk van Christus heft de geschapen werkelijkheid zoals de Schrift daarover spreekt, niet op. Christus heeft deze werkelijkheid juist bevestigd en in beginsel hersteld. Daarmee moet de theologie waken tegen datgene wat die orde die het welzijn van mensen dient, bedreigt, en mag zij tegelijkertijd uitzien naar wat boven die orde uitgaat, zonder afwijzing van de geschapen orde. ${ }^{19}$ Heel de Schrift getuigt dat man en vrouw twee fundamentele bestaanswijzen van het mens-zijn vormen. De verhouding tussen God en zijn volk, en ook de verhouding tussen Christus en zijn gemeente, wordt vergeleken met de verhouding tussen man en vrouw. Dat sluit oprechte aandacht voor gebrokenheid niet uit, zoals ook bijvoorbeeld blijkt uit het spreken van de Schrift over eunuchen (vgl. Mat.19,12).

\section{Scheppingswerk}

De Schrift getuigt dat God eerst Adam formeerde (vgl. 1Tim.2,13). Hij had echter niet de intentie daarmee te volstaan. Zijn intentie was de schepping van man én vrouw, die gezamenlijk Hem zouden moeten representeren en in zijn Naam de aarde beheren. Michelangelo schilderde in de Sixtijnse kapel God de Vader die Adam tot leven wekte, terwijl Hij Eva al onder zijn arm had. Beiden hebben - schepselmatig gezien - een eigen structuur en functie. Deze betreffen zowel hun lichaam als hun geest, omdat lichaam en geest één zijn. Man-zijn wordt niet uitsluitend bepaald door hormonen, klieren en uitwendige organen. Het gehele mens-zijn is daarvan doortrokken: de mens wordt niet vanaf een bepaalde dag in zijn ontwikkeling een mannelijk wezen, maar is dat vanaf zijn geboorte. Geslachtelijkheid doordringt zijn mens-zijn. Dit man-zijn is na de zondeval niet verloren gegaan, maar - dankzij de genade van God - bewaard gebleven. Wel is deze bestaanswijze geschonden en verstoord geraakt. Deze gebrokenheid raakt geheel zijn lichamelijke en psychische constitutie. ${ }^{20}$

Bij zijn schepping ervoer de eerste mens een gebrek. Hij merkte dat hij alleen was. Zijn bestaan werd gekenmerkt door behoefte aan hulp en bijstand, aanvulling en completering. Deze behoefte uit zich - opnieuw: schepselmatig gezien - in het verlangen naar en completering door een levensgezel. Dit ver-

19 Oliver O’Donovan, Resurrection and Moral Order. An Outline for Evangelical Ethics, Leicester 1986, 15.

20 In het vervolg van dit artikel wordt enige aandacht gegeven aan de conditie van intersekse en genderdysforie. 
langen heeft allereerst betrekking op zijn aardse bestaan. Maar niet alleen daarop; het is een schaduw van een groter verlangen. Alleen God kan uiteindelijk zijn diepste verlangen vervullen. De mannelijke bestaanswijze heeft derhalve een theologische dimensie. Het verlangen naar completering is een teken van het verlangen naar volkomen vervulling daarvan door de band met God. ${ }^{21}$

In antwoord op het 'aardse' verlangen van Adam heeft God een vrouw geschapen. Het zou niet goed zijn als hij alleen zou blijven. 'Alleen' heeft hier de klank van onvolledig. God gaf hem als 'onvolledige schepping' een naaste die aan hem gelijk is. Zoals Adam zich bewust werd van zijn onvolledigheid, zo wordt ook de man - bij wijze van spreken - dagelijks aan zijn eigen onvolledigheid herinnerd door de aanwezigheid van zijn vrouwelijke medemens, die ontologisch gezien aan hem gelijk is maar toch ook anders. Dit verschil is fundamenteel, omdat het teruggaat op een directe scheppingsdaad van God. Het is daarom fundamenteler dan het verschil tussen vader en zoon, moeder en dochter, en tussen mensen van verschillende leeftijd en met verschillende gaven en karaktertrekken. Het gaat door alle andere onderscheidingen heen. Het is meer dan een variatie, waarachter een neutraal, abstract mens-zijn ligt. In hun anders-zijn vullen zij elkaar aan en geven zij invulling aan hun eenheid. In geen enkel andere verhouding zijn mensen met lichaam en ziel zó op elkaar aangewezen en afhankelijk van elkaar. Hun verlangen naar elkaar krijgt ook - schepselmatig gezien - gestalte in een verlangen naar lichamelijke eenwording. Deze eenwording onderstreept dat zij beiden delen in het mens-zijn. Zij horen niet bij twee verschillende 'soorten'. Beiden zijn zij volledig mens en daarmee beeld van God (Gen.1,27; 9,6; Jak.3,9), maar elk op hun eigen wijze.

Wat in het voorgaande over de man is gezegd, geldt ook voor de vrouw. Schepselmatig gezien doortrekt haar vrouwelijkheid heel haar doen en laten. Lichaam en psyche zijn een. Dat is na de zondeval niet geheel verloren gegaan, maar wel aangetast. Deze aantasting kan zich manifesteren op lichamelijk vlak, in haar ontwikkeling. Ook kan deze aantasting zich manifesteren in haar zelfbeeld en in haar houding ten opzichte van haar eigen lichamelijke constitutie.

\section{Rollen en identiteit}

Hoewel het verschil tussen man en vrouw genetisch en hormonaal gezien betrekkelijk gering is, is het effect van dat verschil groot, alleen al gezien hun lichaamsbouw. Eeuwenlang is dit verschil onderstreept, onder meer in de rollen die mannen en vrouwen werden toebedeeld. Hedendaagse kennis onderstreept het verschil in constitutie, dat vooral blijkt in het reproductieproces.

21 Vgl. bijv. Stanley J. Grenz, Sexual Ethics. An Evangelical Perspective, Louisville 1997, 34.36. 
Hoe dichter menselijke functies met dit proces verbonden zijn, hoe meer de verschillen tot uiting komen. Duidelijk is in elk geval dat het vrouw-zijn in meer bestaat dan de mogelijkheid tot het baren van een kind. Het is verweven met heel haar bestaan, ook in haar psychische constitutie. De man is - zo wordt gezegd - over het algemeen genomen rationeler ingesteld en abstracter denkend dan de vrouw. Hij zou zijn gevoelens minder gemakkelijk uiten en avontuurlijker zijn ingesteld. Een vrouw daarentegen zou meer gericht zijn op concrete dingen, een sterkere intuïtie hebben, beter in staat zijn gevoelens te uiten en ten slotte zorgzamer zijn.

De vraag daarbij is of de verschillen daadwerkelijk zo groot zijn als weleens is voorgesteld. En ook of die eventuele verschillen - afgezien van de relatie van beide bestaanswijzen tot mogelijkheden met betrekking tot het reproductieproces - terug te leiden zijn tot het scheppingswerk van God. Mannelijkheid en vrouwelijkheid krijgen in elke concrete omgeving, tijd en cultuur een concrete invulling. Maar dát er significante verschillen tussen karaktereigenschappen van jongens en meisjes, mannen en vrouwen zijn, leeft wel breed in de samenleving. De filosofe Griet Vandermassen gebruikt de evolutietheorie om duidelijk te maken hoe groot deze verschillen zijn. Jongens hebben overwegend meer interesse in omgaan met objecten, en vrouwen in het omgaan met mensen. Hoe welvarender een maatschappij wordt en des te meer keuzevrijheid er is voor vrouwen, hoe groter de sekseverschillen in studie- en beroepskeuze worden. Wanneer vrouwen keuzevrijheid hebben, kiezen zij eerder voor studies en banen die gericht zijn op mensen in plaats van op objecten, juist omdat ze de kans krijgen om hun eigen interesses te volgen. Het bewijs is volgens Vandermassen overweldigend dat veel psychologische sekseverschillen niet alleen aan opvoeding en cultuur liggen, maar een voorspelbaar gevolg zijn van een proces van miljoenen jaren van evolutie. ${ }^{22}$

De klassieke gereformeerde ethiek oriënteert zich echter aan de Schrift: God schiep twee bestaanswijzen. Evident is er een schepselmatig verschil in biologisch en anatomisch opzicht. Ook zijn de schepselmatige mogelijkheden in het proces van reproductie duidelijk. Wat het verschil in karaktereigenschappen betreft, liggen de zaken niet altijd even helder. De verschillen binnen de ene (mannelijke of vrouwelijke) bestaanswijze zijn soms groter dan de verschillen die in het algemeen worden aangeduid tussen de beide bestaanswijzen. De werkelijkheid is complex. Is de man sterk en de vrouw zwak? Gaat

22 In haar Dames voor Darwin (Feminisme en evolutietheorie, Antwerpen 2019) geeft Griet Vandermassen een overzicht van actueel onderzoek naar psychologische en gedragsverschillen tussen mannen en vrouwen. 
hij voorop en volgt zij? Wat sterkte en zwakte, voorgaan en volgen inhoudt, is niet direct duidelijk. De theologie kan karakterverschillen niet in een theorie vastleggen. En als er verschillen in karakter en psychische structuur kunnen worden aangewezen, is het de vraag hoe deze moeten worden geduid, en wat kan worden toegeschreven aan wat nu eenmaal met het man- of vrouw-zijn is gegeven, en wat het resultaat is van cultuur, omgeving en opvoeding.

Bovendien mogen verschillen die door de cultuur zijn bepaald, niet zomaar worden geprojecteerd op de scheppingswerkelijkheid. Wat God bij de schepping bedoelde en wat door de zondeval in de menselijke werkelijkheid is binnengedrongen, is niet altijd direct duidelijk. De rolverdeling tussen man en vrouw die tot ver in de $20^{\text {ste }}$ eeuw in de westerse wereld gold, mag niet worden gelijkgesteld met wat God bedoelde in het begin. Kerk en theologie moeten waken voor een ongenuanceerd beroep op de natuur waarbij de biologie zou voorschrijven wat de precieze rollen van mannen en vrouwen zouden zijn. In het man- of vrouw-zijn is veel variatie. Toch kan een theologie die gereformeerd wil zijn, niet om het spreken van de Schrift heen: 'mannelijk en vrouwelijk schiep Hij hen', en ordende voor hen een intieme, alomvattende en blijvende levensverbintenis.

Man en vrouw zijn dan niet alleen twee wijzen van beeld-zijn, maar ook sámen beeld van God. God schiep deze tweeslachtigheid met een structureel verlangen naar completering, omdat Hij wilde dat mensen Hem zo op aarde zouden vertegenwoordigen en aan elkaar verbonden zouden zijn. $\mathrm{Zij}$ moeten samen zorgdragen voor de aarde. Mannelijk of vrouwelijk mens-zijn is een fundamentele drive voor relationaliteit. Dualiteit in de mensheid roept om coexistentie en ook om pro-existentie: een bestaan voor elkaar. Deze verbondenheid uit zich in eerste instantie in een intieme huwelijkse levensverbintenis, vervolgens in een huisgezin, en dan ook in bredere sociale verbanden.

Eeuwenlang werden aan de mannelijke en vrouwelijke bestaanswijze bepaalde rollen toebedeeld. De man zorgde in een traditionele samenleving voor de bescherming van zijn vrouw en kinderen, en voor het inbrengen van voedsel voor het huis(gezin). De rol van de vrouw was sterk verbonden met de mogelijkheid kinderen ter wereld te brengen. Zij zorgde voor kleding en voedsel in huis, en was daarnaast voor de man een helper in het werk van voortplanting. De vrouw had een tweederangsstatus. Ook in de Reformatie kwamen de eigen roeping en bestemming van de vrouw niet geheel uit de verf. Van de oude gedachte dat de vrouw eigenlijk een niet-perfecte mens is, werd niet duidelijk afstand genomen. Als Calvijn in zijn Institutie spreekt over de mens als beeld van God (I,15), noemt hij het vrouw-zijn niet. De vrouw komt pas ter sprake in boek II $(8,43)$, bij de uitleg van het zevende gebod. Pas in de $17^{\text {de }}$ en $18^{\text {de }}$ eeuw kwam er meer oog voor de eigen waarde 
van de vrouwelijke sekse. Maar het traditionele rolpatroon, waarbij de man een leidende en de vrouw een dienende rol heeft, bleef daarbij voor een belangrijk deel nog tot in de $20^{\text {ste }}$ eeuw bestaan. In de traditie van kerk en theologie is dit model verdedigd met een beroep op de scheppingsordening. Daarbij is echter niet altijd rechtgedaan aan de eigenheid van de vrouwelijke bestaanswijze en de roeping die God haar heeft gegeven.

Evident is dat de Bijbel spreekt over een dualiteit in het mens-zijn: de mens is - schepselmatig gezien - mannelijk óf vrouwelijk. Heel de Schrift kent deze dualiteit. Een theologie die zich oriënteert aan de Schrift als haar primaire kennisbron, kan daar niet omheen. Wie dat spreken loslaat, vervreemdt zich niet alleen van het spreken van de Schrift maar ook van de ordeningen die God heeft gegeven.

\section{Gebrokenheid}

Tegelijkertijd moeten kerk en theologie rekening houden met gebrokenheid op dit terrein. Deze gebrokenheid kan hierin bestaan dat de sekse onduidelijk is. Mensen kunnen daardoor ernstig lijden ervaren. Bij dit alles blijft staan dat God geen tweederangsbeelden kent. Zo is er overigens wel over gesproken, ook door theologen. Augustinus bijvoorbeeld sprak ten aanzien van hermafrodieten over 'monsters'. ${ }^{23}$ Dit spreken uit onkunde is helaas in de geschiedenis meer dan eens herhaald. Daar staat tegenover dat God ieder mens aanspreekt op zijn beeld-zijn, hoe ernstig de gebrokenheid in zijn sekse ook is.

In welke zin moeten kerk en theologie daar rekening mee houden? Die vraag speelt vandaag vooral ten aanzien van het al of niet verrichten van een geslachtsveranderende ingreep. Steeds vaker wordt bij genderdysforie een dergelijke ingreep toegepast. De reden daarvoor is onder meer dat de inzet van psychiatrische hulp bij genderdysforie zijn grenzen heeft. Therapieën die gericht zijn op verandering van genderidentiteit, hebben doorgaans weinig of geen succes. Op zichzelf is dat begrijpelijk als ervan wordt uitgegaan dat de oorzaak van de dysforie ligt in biologische en genetische factoren; misschien minder begrijpelijk als de oorzaak ligt in ontwikkelingspsychologische en sociale factoren. Voor een lichamelijke transitie is iets te zeggen als de betrokken persoon grote psychische nood ervaart, geen baat heeft bij psychiatrische hulp, maar wel baat kan hebben bij een dergelijke ingreep. Volgens J. Douma is 'niet in te zien waarom we alleen maar zouden mogen proberen de psyche bij het lichaam aan te passen' door psychotherapie en waarom we ook niet het 
lichaam bij de psyche zouden mogen aanpassen. ${ }^{24}$ Zo meent ook M. Valenkamp dat dan niet alleen de principes van eerbied voor of heiligheid van het leven moeten gelden. Het uitgangspunt moet volgens hem de vraag naar de kwaliteit van het menselijk leven zijn. ${ }^{25}$ Het punt is echter of een ingrijpende omvorming van een lichaam dat op zichzelf in orde is, verantwoord is. Op zichzelf kan het verantwoord zijn om aan de nood van de betrokken persoon tegemoet te komen en deze te lenigen. Toch loert hier ook een gevaar, namelijk dat in deze diepe ingreep in het menselijk lichaam het lichaam wordt onderschat, dat het eigenlijke 'ik' wordt gelokaliseerd in het bewustzijn en het 'ik' van het lichamelijke bestaan daaraan ondergeschikt wordt gemaakt. ${ }^{26}$

Wie in deze problematiek een beslissing moet nemen, kan kiezen uit een aantal opties. De eerste optie is het accepteren van een lichamelijke transformatie. Wie ernstig lijdt aan genderdysforie, zal een dergelijke transformatie zien als een laatste middel om los te komen van een zware last. Gezien dit lijden en de mogelijkheden van de medische wetenschappen hierin verlichting te brengen zal er begrip zijn voor diegenen die kiezen voor een transitie. ${ }^{27} \mathrm{Zij}$ doen dat dan niet omdat zij menen dat hun lichaam materiaal is dat zij naar eigen inzicht mogen herschikken op zoek naar geluk, maar vanuit een diepe, existentiële nood.

De tweede optie is het afwijzen van een dergelijke ingreep. Zo doen veel rooms-katholieke en evangelicale theologen. Er wordt dan gewezen op het feit dat dan wordt ingegrepen in een lichaam waaraan anatomisch, genetisch en hormonaal niets mankeert. Er moet (naast de Schrift ook) geluisterd worden naar de stem van de natuur. Het 'ik' van de psyche heeft geen zeggenschap over het ' $\mathrm{ik}$ ' van het gezonde lichaam. Acceptatie van een herschikking van de lichamelijke constitutie zou dan een capitulatie zijn voor een moderne ideologie, die het lichaam ondergeschikt maakt aan de geest. Daarnaast wordt de vraag gesteld wat een dergelijke transformatie doet met de directe sociale omgeving. Welk effect heeft een transitie als kinderen hun moeder voortaan papa moeten noemen en zij daardoor opeens twee papa's hebben? Wat doet

24 J. Douma, Medische ethiek. Christelijke ethiek 6, Kampen 1997, 348.

25 M. Valenkamp, 'De problematiek van transsexualiteit en operatieve veranderingen aan het menselijk lichaam vanuit wijsgerig-antropologisch en ethisch perspectief, in: Koers. Bulletin for Christian Scholarship/Bulletin vir Christelike Wetenskap 56,3 (1991), 404: met nadruk op 'menselijk'.

26 Vgl. W.J. Eijk, L.J.M. Hendriks en J.A. Raymakers, Handboek Katholieke Medische Ethiek. Verantwoorde gezondheidszorg vanuit katholiek perspectief, Almere 2010, 352-353.

27 Vgl. Mark A. Yarhouse, Understanding Gender Dysphoria. Navigating Transgender Issues in a Changing Culture, Downers Grove 2015. 
een transitie met het beeld dat mensen daardoor krijgen van het bijbelse spreken over man en vrouw? Bovendien werpt een transitie voor de betrokkene nieuwe problemen op, vooral als hij of zij zich wil laten leiden door de normen van God ten aanzien van de levensverbintenis tussen man en vrouw. Mag een man die de geslachtskenmerken van een vrouw heeft aangenomen, een huwelijkse verbintenis met een man aangaan, terwijl zij/hij genetisch gezien een man is en blijft? Moet hij/zij dan een relatie met een vrouw aangaan? Wat telt? Het sociale, juridische geslacht of het genetisch-biologische geslacht?28

Zou de kerk moeten kiezen tussen een van beide opties? Bedacht moet worden dat zij een eigen boodschap heeft. Zij is geroepen tot verkondiging van het evangelie, ook voor diegenen die worstelen met deze problematiek. Zij is méér dan raadgeefster in een sociaalpsychologische of medisch-wetenschappelijke casus. Haar taak is naast diegenen staan die vanuit ernstige psychische nood deze stap overwegen. Zij zal diegenen die worstelen met hun dysforie of een andere gebrokenheid in sekse zoals de conditie van interseks, moeten bijstaan vanuit de gezindheid van Christus.

Haar boodschap is dat zij niet zonder meer een lichamelijke transformatie afwijst. Tegelijkertijd accepteert zij niet zonder meer een dergelijke transitie. Zij wijst allereerst op een christelijk omgaan met gebrokenheid en lijden. Deze weg is noch een 'eenvoudige' afwijzing, noch een 'eenvoudige' acceptatie, maar een vorm van acceptatie die uitgaat boven een acceptatie als menselijk construct. ${ }^{29} \mathrm{Zij}$ mag een acceptatie verkondigen die vanboven komt. Daarin mag zij de gelovige raad geven, die dan zijn verantwoordelijkheid kan verstaan. Wie lijdt aan een of andere gebrokenheid, mag en móet ook zijn verantwoordelijkheid verstaan. Hij zal dan niet kiezen voor een lichamelijke transformatie. ${ }^{30} \mathrm{Zijn}$ lichaam is niet geschonden noch misvormd. Wel mag hij weten van de verandering die het evangelie geeft: het evangelie spreekt over transformatie in Christus. Wie in Christus is, is een nieuwe schepping! De gelovige beseft dat zijn identiteit niet opgaat in zijn sekse. Zijn lichaam is niet zijn ultieme werkelijkheid. Wat voor hem telt, is 'zijn in Christus'.

De uitdaging voor de kerk die hiermee te maken heeft, is niet dat zij argumenten bedenkt waardoor zij ruimte zou kunnen vinden voor de acceptatie

28 Vgl. Oliver O’Donovan, 'Transsexualism and Christian Marriage', in: Journal of Religious Ethics 11 (1983). Dit artikel is eerder in kortere vorm uitgegeven: id., Transsexualism. Issues and Argument. Grove Ethic Series E 147, Cambridge, 2007 [1982].

29 Samuel Wells spreekt over overaccepting als alternatief voor blocking en accepting. Zie zijn Improvisation. The Drama of Christian Ethics, Grand Rapids 2004.

30 Hier is niet gezegd dat hij of zij dat 'nooit' zal doen. Wordt ertoe besloten, dan kan dat niet anders zijn dan een ultiem middel. 
van een lichamelijke transitie van iemand die de gebrokenheid tussen lichaam en psyche als een zware last ervaart. Haar uitdaging is wel dat zij de belofte van het evangelie gestalte kan geven voor de betrokken persoon, waardoor zijn last dragelijk wordt. In Christus is de gelovige daadwerkelijk vernieuwd. De belofte van het evangelie is ook dat hij dagelijks door de Heilige Geest wórdt vernieuwd. Deze belofte gaat verder dan de belofte van een lichamelijke transitie.

De gelovige beseft dat navolging van Christus juist plaatsvindt in gebrokenheid en lijden, en dat Christus zijn kracht in menselijke zwakheid en gebrokenheid tot openbaarheid laat komen. Dan wordt niet elke last van zijn schouders afgenomen en niet elke gebrokenheid geheeld. Dan is vaak eerder care nodig, dan een streven naar cure. Navolging van Christus gebeurt altijd in gebrokenheid, in lijden en onder lasten, in een gebroken wereld. Voor de gelovige vindt die navolging plaats samen met medegelovigen in het midden van een geloofsgemeenschap. Daar mag hij leren wat het in de praktijk betekent Christus na te volgen. De beslissende vraag is dan hoe haar antwoord op dit vraagstuk een vernieuwing van het geloof en de geloofspraktijk van de kerk kan bevorderen. ${ }^{31} \mathrm{Zij}$ verschilt met haar omgeving door een andere visie op de gebrokenheid in de wereld en omgaan daarmee, én het verwelkomen van diegenen die als 'vreemd' worden ervaren. ${ }^{32}$

De kerk die in de traditie van de Reformatie wil staan, moet te midden van de tendens in de samenleving en ontwikkelingen op het terrein van sekse en gender haar positie bepalen. Als zij echter haar spreken over twee seksen zou loslaten, zou ze het bijbelse spreken schade toebrengen. Dat laat onverlet dat zij diegenen die gebrokenheid ervaren in hun sekse tegemoet moet treden in de gezindheid van Christus. Hun beeld-van-God-zijn staat niet ter discussie. Zowel de man als de vrouw is ten volle mens, en óók diegene die juist daarin gebrokenheid ervaart.

D.J. Steensma is docent ethiek aan de Theologische Universiteit van de Christelijke Gereformeerde Kerken te Apeldoorn, en predikant van de Christelijke Gereformeerde Kerk te Feanwâlden. Dit artikel is een bewerking van een integratiecollege aan de TUA op 3 februari 2020.

31 Vgl. Wells, Improvisation, 197.

32 Vgl. Wells, Improvisation, 198. 